\title{
A Study of Clinical and Demographic Profile of Subjects with Snake Bite in a Tertiary Care Centre, Mysuru
}

\author{
Basavaraju M M ${ }^{1}$, Ramesh S S ${ }^{2}$, Shinto K Thomas ${ }^{3}$, Varsha Ravindra Bhandarkar ${ }^{4}$ \\ ${ }^{1}$ Associate Professor, Department of Medicine, Mysore Medical College and Research Institute, ${ }^{2}$ Associate Professor, \\ Department of Medicine, Mysore Medical College and Research Institute, 3Junior Resident, Department of Medicine, \\ Mysore Medical College and Research Institute, ${ }^{4}$ Junior Resident, Department of Medicine, Mysore Medical College and \\ Research Institute
}

Corresponding author: Dr.Ramesh S S, Associate Professor, Department of Medicine, Mysore Medical College and Research Institute

DOI: http://dx.doi.org/10.21276/ijcmsr.2019.4.1.18

How to cite this article: Basavaraju M M, Ramesh S S, Shinto K Thomas, Varsha Ravindra Bhandarkar. A study of clinical and demographic profile of subjects with snake bite in a tertiary care centre, Mysuru. International Journal of Contemporary Medicine Surgery and Radiology. 2019;4(1):A74-A77.

\section{A B S T R A C T}

Introduction: Snake bite is a common medical emergency faced mainly by the rural populations in tropical and subtropical countries including India with heavy rainfall and humid climate. Incidence and frequency of snake bites varies across the different geographic regions with in the country depending on factors such as climate, ecology, biodiversity, distribution of snakes. The present study was undertaken to find out the clinical and demographical profile of subjects with snake bite.

Material and Methods: This study was done in KR hospital Mysuru,a tertiary care centre.351 subjects with history of snake bite were included in the study after taking informed written consent. Snake bite was diagnosed with proper history taking and detailed examination for fang marks and local and systemic complications.Details were tabulated in to Microsoft excel software and analysis of data was done with SPSS software version 20.

Results:The present study included 351 subjects admitted with snake bite with a male to female ratio of 2.4 and an age mean of 38.9 \pm 12.54 . Majority of the subjects were from Mysore(35.6\%), and coolie workers and farmers(31.6\%).76 \% had unknown snake bite, $13.6 \%$ had cobra bite and $6.3 \%$ had viper bite. $88 \%$ of the subjects reached hospital with in 6 hours.69.8\% had snake bite on lower limb,15.8\% of subjects developed renal dysfunction.

Conclusion: Snake bite is a common medical emergency which is treatable and complications are preventable. It is more common among male farmers and coolie workers during the rainy season (July to September).Since majority of the bites are unknown, clinical examination for signs of envenomation is important to manage snake bites effectively. Delay in attending proper medical care because of poor knowledge about treatment and still prevailing myths and traditional methods leads to complications

Keywords: Snake Bite, Karnataka, Demographic Profile

\section{INTRODUCTION}

Snake bite is a common medical emergency faced mainly by the rural populations in tropical and subtropical countries including India with heavy rainfall and humid climate. WHO estimates the problem as 4,21,000 envenomation and 20,000 deaths per annum. The same report also suggest that the burden may be ashigh as $1,841,000$ envenomation and 94,000 deaths globally. India is reported to have highest number of deaths due to snake bites in the world. World Health Organization (WHO) estimates place the number of bites to be 83,000 per annum with 11,000 deaths. ${ }^{1}$

There are more than 2000 species of snakes in the world and about 300 species are found in India out of which 52 are venomous. There are about 236 species of snakes in India, most of which are nonpoisonous. However, there are 13 known species that are poisonous and of these four, namely common cobra (Najanaja), Russell's viper (Dabiolarusselii), saw-scaled viper (Echiscarinatus) and common krait (Bungaruscaeruleus) are highly venomous and believed to be responsible for most of the poisonous bites in India. ${ }^{2}$

Snakebite incidences and the associated mortality vary from region to region and depend upon the natural habitat of the venomous species of snake, the geographical region, probability of human beings coming in contact with snakes, knowledge of medical aid, appropriate medical facilities (especially availability of antivenoms), and the experience of the attending physician. This study was aimed at studying the clinical and demographic profile of subjects with snake bite in southern Karnataka.

\section{MATERIAL AND METHODS}

The present study was carried out over a period of one year (January $1^{\text {st }}$ to December $31^{\text {st }} 2017$ ) in our hospital which is a tertiary care centre and teaching institute in southern part of state of Karnataka. All those patients who are $>18$ 
years of age and presenting to the casualty department with alleged history of snake bite were included in the study and prospectively studied for the symptoms and signs of envenomation. Snake bite and species identification were confirmed by a reliable history from patient, those who witnessed the bite and patients bystanders. All patients were interviewed using a standard questionnaire to maintain a record of patients history relevant to snake bite envenomation. In this study all cases of snake bite $\geq 18$ years of age who have given informed written consent were included according to inclusion and exclusion criteria. A detailed clinical history and thorough clinical examination was done.

\section{Inclusion Criteria}

Subjects above 18 years of age

Subjects who are admitted with alleged history of snake bite

\section{Exclusion criteria}

Subjects who have not given written informed consent

\section{Investigations}

All patients who got recruited to our study were undergone the following biochemical tests apart from clinical signs and symptoms of envenomation.

1. Whole blood clotting time

2. Complete haemogram

3. Renal function test

4. Random blood sugar

5. Liver function test

6. ECG.

\section{STATISTICAL ANALYSIS}

Descriptive analysis of the collected data was done and clinical and demographic profile of subjects with snake bite was studied. The statistical analysis was performed using SPSS software version 20.

\section{RESULTS}

The study was done on total 351 subjects with alleged history of snake bite who got admitted in our hospital. $70.7 \%$ of the study subjects were males,29.3\% were females.Maximum number of patients were in the age group 31 to 45 with a mean age of $38.9 \pm 12.54$ years. Majority of the subjects belongs to Mysuru (47.5\%). $21.6 \%$ subjects came from Mandya, $11.3 \%$ of subjects came from Chamrajnagara.

Majority (76\%) of the bites were unknown. Among others $6.3 \%$ were admitted with Viper bite, $13.6 \%$ with Cobra bite and $3.9 \%$ with krait bite.Irrespective of the geographical area Cobra bite was the most common among known bites. Most of the subjects were agricultural coolie workers(39.6\%). $31.6 \%$ were farmers, $9.9 \%$ were house wife.Maximum number (43.8\%) of snake bite cases got admitted in July to September as compared to $23.9 \%$ in April to June,13.6\% in January to March, $18.5 \%$ in October to December.

Maximum number of subjects reached hospital with in 2-4 hours (52.9\%). 22.7\% reached with in $<2$ hours, $10.5 \%$ reached wit in 5-6 hours. Most of the subjects had bite on lower limb (69.2\%) followed by upper limb (28.2\%).

Among the study subjects $43.5 \%$ had no signs of envenomation, $37.8 \%$ had local signs without systemic signs, $63 \%$ had both systemic and local signs of envenomation. 40

\begin{tabular}{|c|c|c|}
\hline Demographic profile & $\begin{array}{l}\text { Number of } \\
\text { subjects }\end{array}$ & $\begin{array}{l}\text { Percentage } \\
\text { of subjects }\end{array}$ \\
\hline \multicolumn{3}{|l|}{ Gender Distribution } \\
\hline Male & 103 & 70.7 \\
\hline Female & 248 & 29.3 \\
\hline \multicolumn{3}{|l|}{ Age distribution(years) } \\
\hline $18-30$ & 127 & \\
\hline $31-45$ & 131 & \\
\hline $46-60$ & 64 & \\
\hline$>60$ & 29 & \\
\hline \multicolumn{3}{|l|}{ Geographical location } \\
\hline Mysuru & 167 & 47.5 \\
\hline Mandya & 76 & 21.6 \\
\hline Chamarajnagar & 40 & 11.3 \\
\hline Hassan & 10 & 2.8 \\
\hline Others & 58 & 16.5 \\
\hline \multicolumn{3}{|l|}{ Type of snake } \\
\hline Viper & 22 & 6.3 \\
\hline Cobra & 48 & 13.6 \\
\hline Krait & 14 & 3.9 \\
\hline Unknown & 267 & 76 \\
\hline \multicolumn{3}{|l|}{ Occupation of subjects } \\
\hline Farmer & 111 & 31.6 \\
\hline Coolie & 139 & 39.6 \\
\hline Student & 11 & 3.1 \\
\hline House wife & 35 & 9.9 \\
\hline Driver & 11 & 3.1 \\
\hline Guard & 4 & 1.1 \\
\hline Others & 40 & 11.3 \\
\hline \multicolumn{3}{|c|}{ Month wise distribution of cases } \\
\hline Jan-March & 48 & 13.6 \\
\hline Apr-June & 84 & 23.9 \\
\hline July-Sep & 154 & 43.8 \\
\hline Oct-Dec & 65 & 18.5 \\
\hline \multicolumn{3}{|c|}{ Time taken to reach hospital(hours) } \\
\hline$<2$ & 80 & 22.7 \\
\hline $2-4$ & 186 & 52.9 \\
\hline $5-6$ & 37 & 10.5 \\
\hline $7-8$ & 12 & 3.4 \\
\hline $9-10$ & 15 & 4.2 \\
\hline$>10$ & 19 & 5.4 \\
\hline
\end{tabular}

\begin{tabular}{|l|c|c|c|c|}
\hline Geographical area & Viper & Cobra & Krait & Unknown \\
\hline Mysore & 11 & 24 & 6 & 103 \\
\hline Mandya & 4 & 9 & 2 & 53 \\
\hline CH Nagara & 2 & 6 & 3 & 29 \\
\hline Hassan & 1 & 2 & 0 & 7 \\
\hline Others & 3 & 7 & 3 & 62 \\
\hline
\end{tabular}

Table-2: Table showing type of snake based on geographical area

(11.3\%) subjects had renal dysfunction in the form of raised blood urea levels. 38 subjects (10.8\%) had renal dysfunction in the form of raised creatinine value. Majority (48.4\%) of the subjects didn't received any first aid before reaching hospital. $37.6 \%$ subjects applied tourniquet before reaching hospital. 


\begin{tabular}{|l|c|c|}
\hline Signs of envenomation & $\begin{array}{c}\text { Number of } \\
\text { subjects }\end{array}$ & $\begin{array}{c}\text { Percentage } \\
\text { of subjects }\end{array}$ \\
\hline Local & 133 & 37.8 \\
\hline Systemic & 20 & 5.6 \\
\hline Local and systemic & 63 & 17.9 \\
\hline No signs & 153 & 43.5 \\
\hline Blood Urea(mg/dl) & 311 & 88.6 \\
\hline$<45$ & 25 & 7.12 \\
\hline $45-90$ & 15 & 4.2 \\
\hline$>90$ & 313 & 89.1 \\
\hline Serum creatinine(mg/dl) & 22 & 6.2 \\
\hline$<1.2$ & 16 & 4.5 \\
\hline $1.2-2$ & 16 & 4.5 \\
\hline$>2$ & 132 & 37.6 \\
\hline Treatment taken before reaching hospital \\
\hline Ayurveda & 22 & 6.2 \\
\hline Tourniquet & 11 & 3.1 \\
\hline Local incision & 170 & 48.4 \\
\hline Others & \multicolumn{1}{|l|}{} \\
\hline None & \multicolumn{1}{|l|}{} \\
\hline \multicolumn{2}{|l|}{ Table-3: Table showing clinical signs and complications } \\
\hline
\end{tabular}

\begin{tabular}{|c|c|c|c|c|}
\hline Gender & $\begin{array}{c}\text { Sharma } \\
\text { et al }{ }^{3}\end{array}$ & $\begin{array}{c}\text { Brunda } \\
\text { et } \mathrm{al}^{4}\end{array}$ & $\begin{array}{c}\text { Chattopadhyay } \\
\text { et al }\left.\right|^{5}\end{array}$ & $\begin{array}{l}\text { Present } \\
\text { study }\end{array}$ \\
\hline Male & $73 \%$ & $76 \%$ & $60 \%$ & $70.3 \%$ \\
\hline Female & $27 \%$ & $24 \%$ & $40 \%$ & $29.7 \%$ \\
\hline
\end{tabular}

\section{DISCUSSION}

The present study included 351 subjects admitted with snake bite with a male to female ratio of 2.4 and an age mean of $38.9 \pm 12.54$.

Male preponderance in our study is in close agreement with earlier studies.It may be attributed to their life styles involving outdoor activities and occupational exposures, while most of the females in our country are house wives,thus less prone for snake bite.

Majority of subjects were in the age group 31-45 (37.2\%). A similar study conducted by Anubha et al in Uttar Pradesh also showed similar age distribution with $60 \%$ of the subjects in the age group 15-45 years.Another study by Amitabha et al showed similar results with maximum number of subjects in the age group 20-40 years.

In the present study majority of the subjects were from Mysore(35.6\%) followed by near by districts Mandya (19.3\%) and Chamrajnagara (11.3\%)

Majority of the bites were unknown snake bite (76\%)in the present study. Among known bites Cobra bite was more common (13.6\%) than Viper (6.3\%) and Krait (3.9\%) bites. Similar study conducted by Shyna ${ }^{5}$ et al showed that majority of the bites were viper (46\%) followed by unknown bites (36\%). Another study conducted by Anubha ${ }^{7}$ et al showed that majority of the bites were by Elapids (46\%) followed by viper (38\%).

In the present study majority of the victims were agricultural coolie workers (39.6\%) followed by Farmers (31.6\%). In an another study conducted by Amitabha et $\mathrm{al}^{6}$ majority of the victims were Farmers (42.3\%) followed by coolie workers (17.3\%).

Seasonal variation is well known in occurrence of snake bite. In present study maximum (43.8\%) cases got admitted to our hospital in the season July to September,which is the rainy season in our area. A similar study conducted by Amitabha et $\mathrm{al}^{6}$ gave similar result with maximum number of cases (50\%) in July to September, followed by $23 \%$ in October to December

$81.1 \%$ of the subjects in the present study reached hospital within 6 hours of snake bite. In a similar study conducted by Shyna $^{5}$ et al, $86 \%$ of the subjects reached hospital with in 6 hours, which is similar to our study.

In the present study majority of subjects had bite on lower $\operatorname{limb}(69.2 \%)$ followed by upper limb (28.2\%). In an another study conducted bu Anubha ${ }^{7}$ et al showed $84.8 \%$ had bite on lower limb. Another similar study by Amitabha ${ }^{6}$ et al showed $71 \%$ bites on lower limb followed by $23 \%$ on lower limb.

Renal dysfunction is one of the most important complication which define the prognosis in snake bite cases. In the present study $11.3 \%$ of the subjects developed renal which is similar to other studies conducted by Amitabha ${ }^{6}$ et al $(15.8 \%)$ and Shyna $^{5}$ et al (6\%).

\section{CONCLUSION}

Snake bite is a common medical emergency which is treatable and complications are preventable. It is more common among male farmers and coolie workers during the rainy season (July to September). Since majority of the bites are unknown, clinical examination for signs of envenomation is important to manage snake bites effectively. Delay in attending proper medical care because of poor knowledge about treatment and still prevailing myths and traditional methods leads to complications (Nearly $40 \%$ of the subjects received traditional treatment before reaching our center)

\section{REFERENCES}

1. Kasturiratne A, Wickramsinghe AR, DeSilva N, et al. The global burden of snakebite: A literature analysis and modelling based on regional estimates of envenoming and deaths. PLOS Med. 2008;5(3):e218.

2. Warrell DA. WHO/SEARO Guidelines for the Clinical Management of Snakebite in the Southeast Asian Region. SE Asian J Trop Med Pub Health. 1999;30(4):1-85.

3. Sharma SK, KhanalB, Pokhrel P, Khan A, Koirala S. Snake bite rapparaisal of the situation in Eastern Nepal. Toxicom 2003;41(6):285-9.

4. Brunda G, Shashidhar RB. Epidemiological profile of snake bite cases from AndraPradeah using immunoanalytical approach. Indian journal of Med Research.2007;41(1):285-9

5. Chattopadhyay MD, Sukul B.A Profile of fatal snake bite cases in the Bankura district of West Bengal. Journal of Forensic Leg Med. 2011;18(5):18-20

6. Shyna KP, Sudhakaran K, Mohammed MTP. A clinical profile of poisonous snake bite in children of North Kerala, India. Int J ContempPediatr 2018;5(2):310-3.

7. Dr. Amitabha Pal. Clinical Profile and outcome of 
Snake bite in patients attending a tertiary care hospital in Bankura, West Bengal. IOSR Journal of Dental and Medical Sciences (IOSR-JDMS) 2018;17(10):34-39.

8. Srivastava A, Gupta A, Singh SK. Epidemiological profile of snake bite at tertiary care hospital, East India. Int J Adv Med 2017;4(2):1422-8.

9. Banerjee RN. Poisonous snakes in India, their venom, symptomatology and treatment of envenomation. In progress in Clinical Medicine in India, 1st Edition, M.M.S. Ahuja Ed. (Arnold Heinman Publishers, New Delhi); 1978:179-86.

10. Anjum, Epidemiological profile of snake bite at tertiary care hospital, North India.J Forensic Res. 2012:3-4

11. Alam MT, Wadud MA. A study of snake bite cases in Faridpur medical college Hospital, Faridpur. Faridpur Med Coll J. 2014;9(1):32-4.

Source of Support: Nil; Conflict of Interest: None

Submitted: 01-02-2019; Accepted: 10-02-2019; Published online: 13-03-2019 